\title{
Complement-Mediated Opsonic Activity in Normal and Infected Human Cerebrospinal Fluid: Early Response During Bacterial Meningitis
}

\author{
André Zwahlen, Urs E. Nydegger, Pierre Vaudaux, \\ Paul-Henri Lambert, and Francis A. Waldvogel
}

\author{
From the Infectious Disease Division and the World Health \\ Organization Immunology Research and Training Center, \\ University Hospital, Geneva, Switzerland
}

\begin{abstract}
A local defense mechanism in bacterial meningitis was evaluated in humans by measuring complement-mediated opsonic activity (CMOA) in normal and infected cerebrospinal fluid (CSF) with a complement-dependent phagocytic bactericidal assay. CMOA was absent in normal untreated CSF and remained undetectable in 20 samples of CSF from patients with viral meningitis and five samples from patients with acute meningococcemia. In contrast, 15 of 27 samples of CSF from patients with acute bacterial meningitis had a measurable $\mathrm{CMOA}$, which was correlated with protein concentrations $(P<0.01)$ and $\mathrm{C} 4$ hemolytic activity $(P<0.001)$ in the CSF. A favorable outcome of bacterial meningitis was associated with the presence of CMOA in CSF ( $P$ $<0.005)$. Recovery was also correlated with higher levels of $\mathrm{C} 4(P<0.01)$ and $\mathrm{C} 3(P$ $<0.05$ ) in CSF and with lower concentrations of microorganisms in the sample of CSF collected at the time of admission $(P<0.01)$. Thus, CMOA, although absent in normal CSF, can appear in CSF during acute bacterial meningitis, particularly in patients who recover completely.
\end{abstract}

Mortality and morbidity from acute bacterial meningitis are still high despite substantial progress in diagnosis and treatment [1-3]. The development and course of meningeal infection are governed by the complex interaction of many variables [4], including $(I)$ microbial virulence factors such as encapsulation [5, 6], (2) clearance of bacteria from the blood [7-9], (3) antibacterial mechanisms in the subarachnoid space [10], (4) anatomic and functional changes resulting from inflammation [11, 12], and (5) antibiotic therapy. Because bacterial meningitis is in essence a closed-

Received for publication June 16, 1981, and in revised form September 15, 1981.

Portions of this work appeared as an abstract (no. 141) in the Proceedings of the 20th Interscience Conference on Antimicrobial Agents and Chemotherapy and in Clinical Research 27:361 A, 1979.

Dr. Zwahlen is the recipient of fellowship no. 83.562.077 from the Swiss National Research Foundation.

We thank Anneliese Kahr, Sonia Grosjean, and Rachel Ballard for technical assistance, Dr. Luc H. Perrin for advice in the complement study, Drs. Gérard Gauthier, Marcelle Megret, Kaplan Riffat, Gregory Szappanyos, and Annie Bellinazzo and Else Budry for help in the collection of cerebrospinal fluid samples, Dr. André Assimacopoulos for technical evaluation of the data, and Françoise Michaud for manuscript preparation.

Please address requests for reprints to Dr. Francis A. Waldvogel, Infectious Disease Division, University Hospital, 1211 Geneva 4, Switzerland. space infection, local defense mechanisms may be important factors that limit bacterial growth. Normal cerebrospinal fluid (CSF) can be considered as a site of a "local defect in host defense," because it contains no phagocytic cells, has a low protein concentration with a predominance of albumin [13], contains no IgM, and has low levels of C3 and $\mathrm{C} 4$ [14-16]. Furthermore, recent studies have suggested that neither $\mathrm{CH}_{50}$ (the amount of complement required to lyse $50 \%$ of sensitized erythrocytes) nor overall bactericidal and opsonic activities are detectable in normal CSF $[17,18]$. As a result, seeding of the CSF with $>10^{3}$ organisms overcomes the clearance mechanisms of the CSF and leads to a rapid multiplication of the microorganisms [19]. Thus, CSF from patients with meningitis often yields initial bacterial counts of $10^{5}-10^{8}$ bacteria $/ \mathrm{ml}$; the higher values are associated with clinical complications [20]. Once established, bacterial meningitis initiates inflammatory reactions in the CSF that result in the generation of chemotactic factors $[21,22]$ and in the appearance of $\mathrm{CH}_{50}$ activity [18], various classes of immunoglobulins $[23,24]$, and polymorphonuclear leukocytes (PMNLs), all of which would be expected to improve the local host defense mechanisms.

Effective opsonization of bacteria by complement and immunoglobulin is an essential step for phagocytosis by PMNLs [25]. Thus, in susceptible 


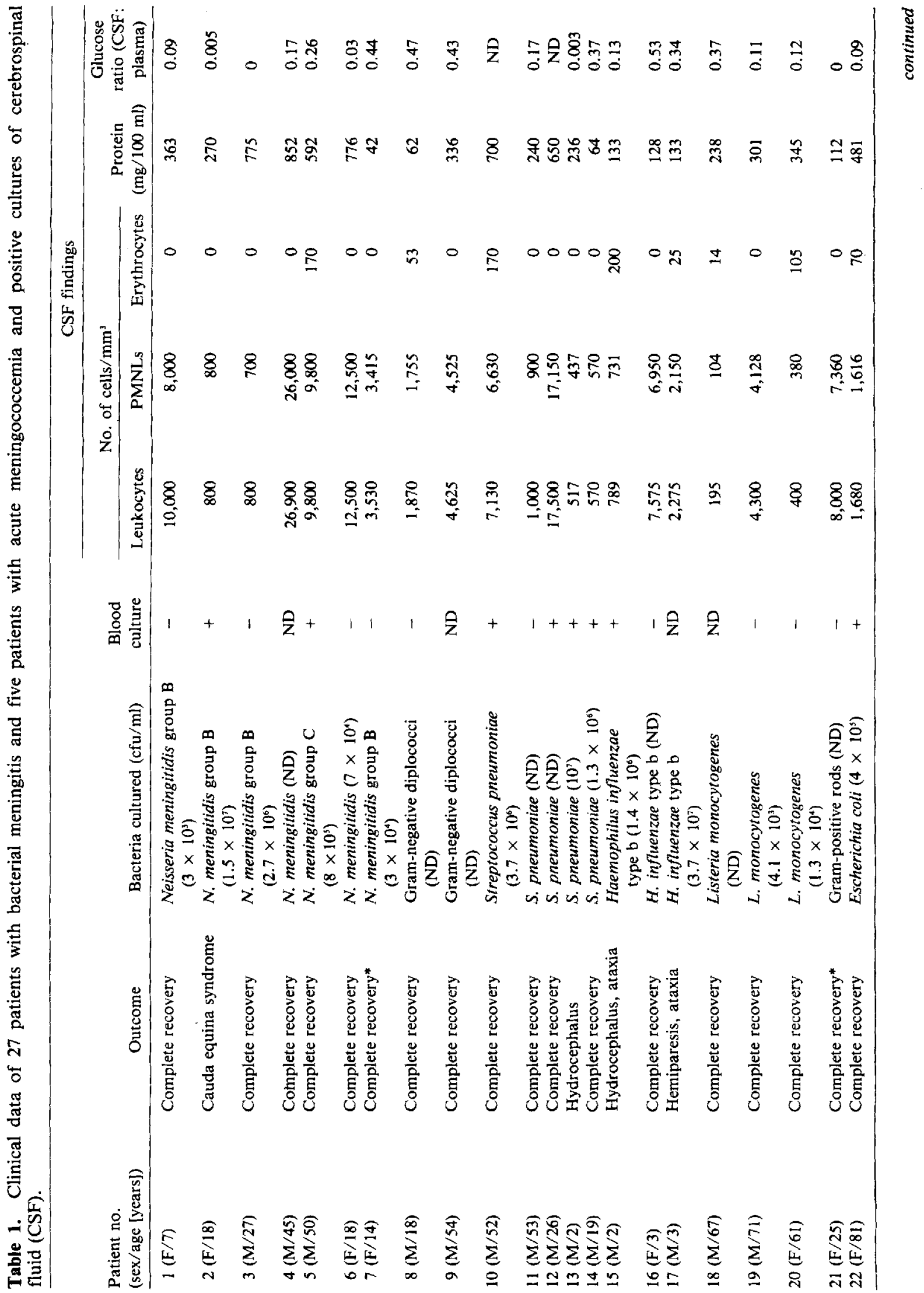




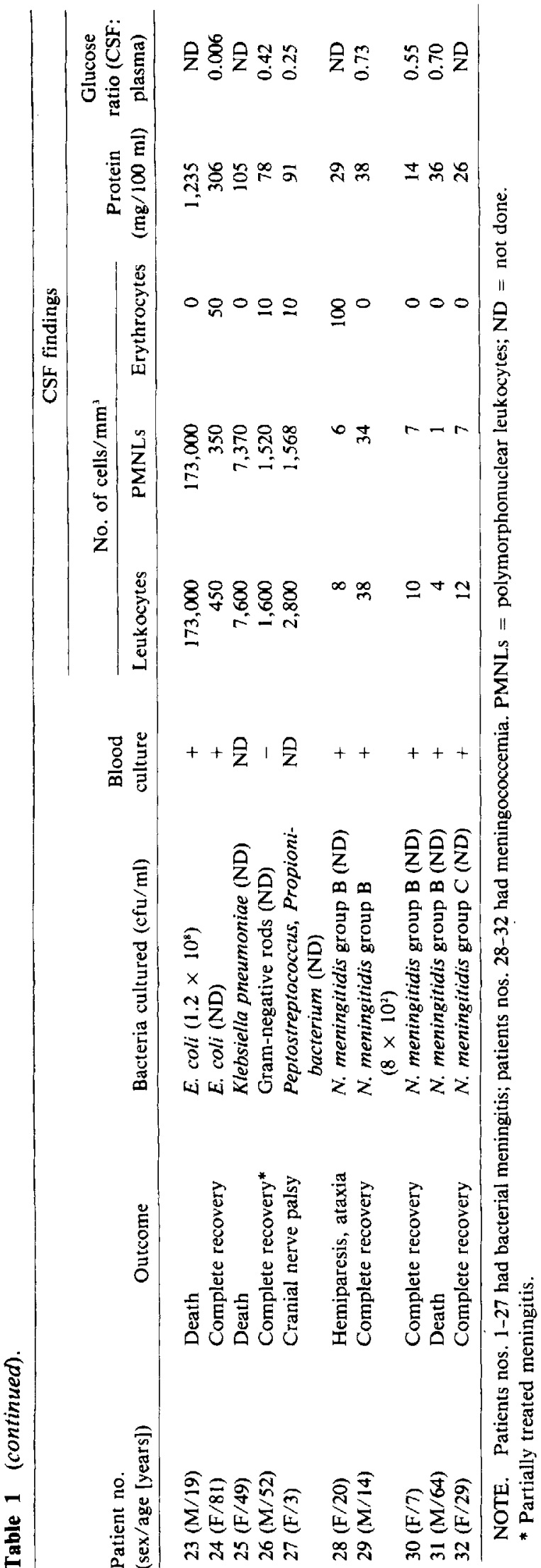

subjects, complement-mediated opsonization may play a crucial role during the early phase of meningitis when specific antimicrobial antibodies are lacking in the serum and CSF.

In the present study we evaluate qualitative and quantitative changes of complement-mediated opsonic activity (CMOA) in normal and infected CSF and try to establish the relation of CMOA to the course and outcome of bacterial meningitis. CMOA and complement levels were measured in the CSF and plasma from uninfected control patients and from patients with viral meningitis.

\section{Materials and Methods}

Patients. Patients who had a diagnostic spinal tap at the University Hospital, Geneva, were prospectively included in the study. Conditions for acceptance were $(I)$ an unequivocal diagnosis based on clinical findings and a CSF sample; (2) availability of a CSF sample from a spinal tap immediately after admission; (3) absence of contamination of the CSF sample by blood, as demonstrated by an erythrocyte count of $<200$ cells $/ \mathrm{mm}^{3}$ and/or a negative hemoglobin test (Labstix ${ }^{\otimes}$; Diethelm Co., Zurich) that detected an admixture of blood in CSF at a dilution of $1: 25,000 ;(4)$ delay of $<6 \mathrm{hr}$ between lumbar puncture and freezing of the CSF (median, $1.5 \mathrm{hr}$; range, 1-6 hr); and (5) absence of degenerative or demyelinating disease of the central nervous system and absence of spinal subarachnoid block. The patients were divided into four groups.

Group 1 consisted of patients with normal CSF. Samples of CSF were taken from 10 patients who had an acute, self-limited, febrile illness and from 15 afebrile patients with suspected disk herniation who underwent diagnostic gas myelography and had normal neuroradiologic findings. Each sample of CSF in this group had a normal protein concentration and a normal cell count. A CSF pool of $15 \mathrm{ml}$ was obtained from a third cohort of 24 normal patients who had spinal anesthesia for surgery.

Group 2 consisted of 20 patients who had viral meningitis; these patients all had a febrile, selflimited disease with signs of meningeal infection that subsided without antibiotic treatment. The patients ranged in age from three to 88 years (median, 29 years). The delay between the onset of symptoms and the diagnostic lumbar puncture 
ranged from 18 to $240 \mathrm{hr}$ (mean, $96 \mathrm{hr}$ ). Viral cultures and serologic studies were not routinely performed, but bacterial cultures of CSF and blood were consistently negative. CSF in this group was characterized by a median leukocyte count of 120 cells $/ \mathrm{mm}^{3}$ with a predominance of lymphocytes, a normal glucose level, and a moderate increase in protein concentration (mean, $45 \mathrm{mg} / 100 \mathrm{ml}$; range, $20-76 \mathrm{mg} / 100 \mathrm{ml}$ ).

Group 3 consisted of five patients (nos. 28-32) who had fulminant meningococcemia - that is, septic shock, petechiae, disseminated intravascular coagulation, and presence of Neisseria meningitidis both in blood and CSF (table 1). One patient died and one was discharged with permanent neurologic sequelae - that is, ataxia and left-sided hemiparesis. The patients' ages ranged from seven to 64 years. Despite CSF cultures that were positive for $N$. meningitidis, these patients had minimal inflammation of CSF, as evidenced by a low leukocyte count (mean, 38 cells $/ \mathrm{mm}^{3}$ ), normal protein concentration, and normal glucose level.

Group 4 consisted of 27 patients (nos. 1-27) who had bacterial meningitis (table 1). Their ages ranged from two to 81 years (median, 25 years). The delay between the onset of symptoms and hospital admission ranged from 12 to $120 \mathrm{hr}$ (mean, $39 \mathrm{hr}$ ). Samples of CSF included in the study were always obtained during the first lumbar puncture and were stored within a median time of 90 min. Pertinent clinical and bacteriologic data and CSF findings are listed in table 1. Of this group, 20 patients recovered completely, five survived with neurologic sequelae (cauda equinea syndrome, hydrocephalus, ataxia, and palsy due to cranial nerve damage), and two died of extensive brain damage.

CSF and blood. To minimize in vitro complement activation, all CSF samples were collected and mixed in tubes that contained EDTA (final concentration, $5 \mathrm{~mm}$ ) and were centrifuged at $1,500 \mathrm{~g}$ for $15 \mathrm{~min}$; the supernatants were stored immediately at $-70 \mathrm{C}$. To obtain serum, blood was allowed to clot at room temperature ( $~ 20 \mathrm{C}$ ) for $60 \mathrm{~min}$, and serum was separated by centrifugation at $1,500 \mathrm{~g}$ for $15 \mathrm{~min}$ and stored at $-70 \mathrm{C}$. To obtain plasma, blood was collected in tubes that contained EDTA (final concentration, 20 $\mathrm{mM}$ ) and centrifuged; the supernatant was immediately stored at $-70 \mathrm{C}$. Protein concentrations were measured in all of the samples of CSF and sera by the Bio-Rad protein assay (Bio-Rad Labo- ratories, Munich). A pool of normal human serum that was obtained from 20 donors was used as a standard. All samples were tested in duplicate. Samples of blood and CSF were cultured, and the microorganisms were identified by standard bacteriologic techniques [26]. Quantitative cultures were obtained from the CSF of 15 patients with bacterial meningitis and one patient with meningococcemia according to the method described by Feldman [27].

Measurements of CMOA in CSF and serum. Preparation of CSF and serum samples. Before being used in the phagocytic assay, each sample of CSF or serum was diluted and reconcentrated three times in an ultrafiltration device with an exclusion limit of 10,000 daltons (model no. PTGC 001-K5; Millipore Corp., Kloten, Switzerland). This procedure, carried out at $4 \mathrm{C}$, was used to eliminate EDTA and to concentrate the immunoglobulins and complement components in Dulbecco's phosphate-buffered saline (pH 7.4; Grand Island Biological Co., Basel, Switzerland).

CMOA was not eliminated by this ultrafiltration procedure as demonstrated by the following experiment: six samples of $1 \%$ normal human serum were submitted either to three consecutive dilution-concentration cycles or to no manipulation; we observed a slight and reproducible loss of CMOA of $44 \% \pm 12 \%$ (mean $\pm \mathrm{SD}$ ) - that is, less than one dilution - when CMOA was evaluated in a phagocytic assay. Similarly, for one patient (no. 22) with bacterial meningitis, a sample of CSF that was obtained before the onset of antibiotic therapy was studied for CMOA before and after the dilution-concentration procedure; the samples showed $50 \%$ killing $\left(\mathrm{K}_{50}\right)$ opsonic titers of 19.8 and 11.9 units $/ \mathrm{ml}$, respectively - that is, a loss of $40 \%$ in opsonic activity after manipulation. Furthermore, no increase of C3d was detected in ultrafiltered plasma. There was no residual antibiotic activity in ultrafiltered samples of serum or CSF as tested by agar diffusion [26] against Staphylococcus aureus variant strain Wood 46.

Preparation of PMNLS. Leukocytes from healthy volunteers were separated from citrated blood by dextran sedimentation. The leukocytes were washed twice and suspended in phosphatebuffered saline at a concentration of $1.25 \times 10^{7}$ PMNLs/ml.

Phagocytic bactericidal assay. The CMOA of the samples was evaluated by a modified phagocytic bactericidal assay [28] using the Wood 46 strain 
of S. aureus. As outlined by Lew et al. [29], strain Wood 46 depends entirely on complement for its opsonization, and no significant phagocytosis or killing occurs in serum that has been inactivated by heating to $56 \mathrm{C}$ for $30 \mathrm{~min}$. Ingestion and killing of the test strain, however, are optimal $(>90 \%$ of the inoculum) in the presence of either normal, agammaglobulinemic, C3-deficient, or $\mathrm{Mg}_{2}$ EGTA-treated $10 \%$ serum. For each $0.5-\mathrm{ml}$ assay, an aliquot of $0.05 \mathrm{ml}$ of bacteria $\left(3 \times 10^{6}\right.$ bacteria/ml) was added to a mixture of $0.4 \mathrm{ml}$ of purified leukocytes $\left(5 \times 10^{6} \mathrm{PMNLs} / \mathrm{ml}\right)$ and 0.05 $\mathrm{ml}$ of serially diluted CSF or serum. The cell suspensions were incubated at $37 \mathrm{C}$ in a shaking water bath, and duplicate samples of the test suspension were drawn at time 0 and after incubation for $30 \mathrm{~min}$. The samples were diluted, and the PMNLs were osmotically lysed with distilled sterile water and plated on Mueller-Hinton agar; the number of residual bacterial colonies was counted after incubation for $24 \mathrm{hr}$. Each of the samples was tested with two controls: (l) heatinactivated serum or CSF with PMNLs and (2) serum or CSF without PMNLs.

Definition of the $K_{50}$ opsonic titers. The $\mathrm{K}_{s 0}$ opsonic titer (expressed in units $/ \mathrm{ml}$ ) was defined as the inverse of the dilution of serum or CSF that promoted $50 \%$ killing of $S$. aureus strain Wood 46.

Measurements of complement factors in CSF and plasma. $\mathrm{CH}_{50}$ was measured in a continuous flow system [30]. C4 hemolytic activity was also tested in a continuous flow system using the plasma of C4-deficient guinea pigs as a source of the other complement components in excess amount [31]. The activity of plasma factor $B$ was assessed by lysis of ${ }^{1} \mathrm{Cr}$-labeled rabbit erythrocytes in the presence of serum devoid of functional factor B activity [32] and was expressed in units $/ \mathrm{ml}$. $\mathrm{C} 3$ and $\mathrm{C} 3 \mathrm{~d}$ levels were measured by immunodiffusion [33, 34], using monospecific antisera (Behringwerke, Marburg-Lahn, Federal Republic of Germany). The levels of the various complement components were measured in duplicate and were expressed as percentages of the levels obtained with a pool of reference standard plasma.

Samples of normal or infected CSF, which were stored in EDTA, were assessed for C4 hemolytic activity as well as for levels of $\mathrm{C} 3$ and $\mathrm{C} 3 \mathrm{~d}$. The techniques that were used to test plasma were used for CSF measurements, but the sensitivity of the assays was increased by using lower dilutions of the samples. The levels of the CSF complement factors were expressed as percentages of those of the pool of standard plasma.

Statistical evaluation. Statistical tests were chosen according to Meddis [35]. Differences between groups were assessed by Student's unpaired $t$-test. Linear correlation coefficients were calculated by a standard program. Mean dose response curves (figure 1) were calculated using the equation described by Wagner [36].

\section{Results}

CMOA in normal CSF and sera. Normal CSF had to be concentrated in order to exhibit CMOA,

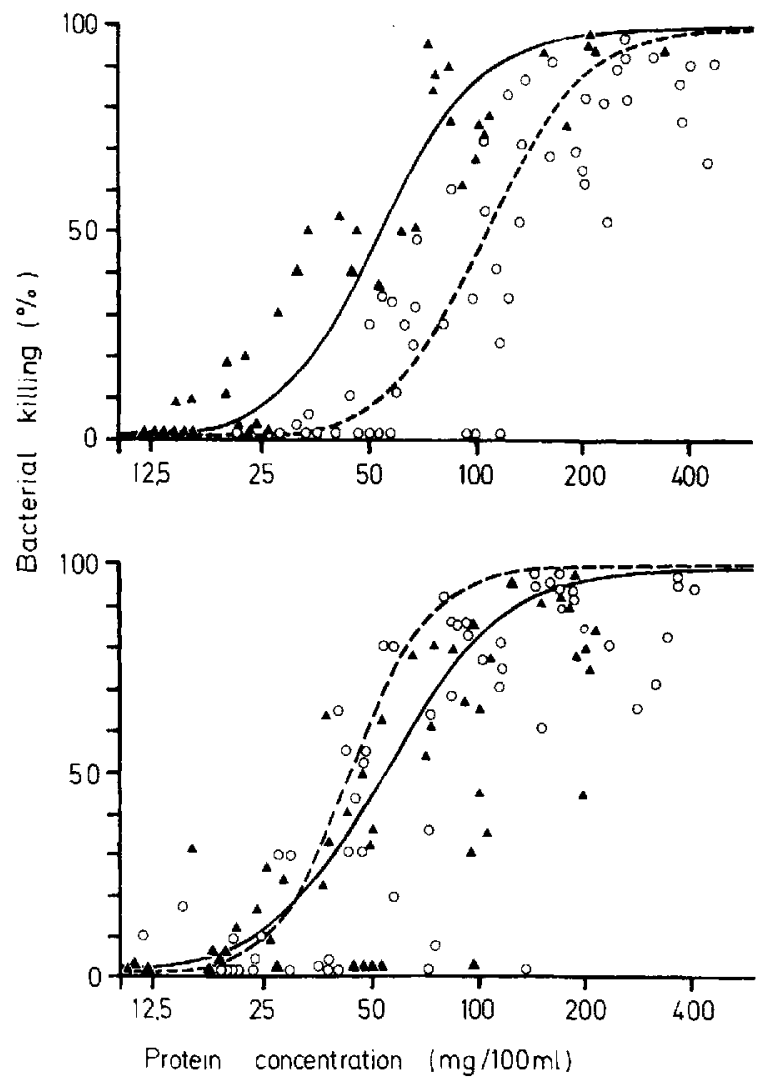

Figure 1. Heat-labile opsonic activity in $(O)$ human cerebrospinal fluid (CSF) and ( $\boldsymbol{\Delta}$ ) serum. The results show the effects of protein concentration in the opsonic source (untreated, concentrated, or diluted CSF and diluted sera) on the percentage of killing of Staphylococcus aureus variant strain Wood 46. Mean dose-response curves were calculated for ( - - ) CSF and (-) serum: (top) 15 samples of CSF and paired sera from subjects without meningitis; (bottom) 15 samples of CSF and paired sera from patients who had acute bacterial meningitis and measurable opsonic activity. 
because neither diluted nor undiluted samples of CSF were able to opsonize $S$. aureus strain Wood 46 (table 2). Addition of purified IgG $(3 \mathrm{mg} / \mathrm{ml})$ or $10 \%$ heat-inactivated serum to untreated CSF did not promote opsonization of the test bacteria. In contrast, a 10-fold concentration of 15 samples of normal CSF obtained during gas myelography (when tested at a final mean [ $\pm \mathrm{SD}$ ] protein concentration of $354 \pm 135 \mathrm{mg} / 100 \mathrm{ml}$ ) allowed for detection of a heat-labile opsonic activity comparable to that of $10 \%$ normal serum. Further evidence for the complement-mediated nature of this opsonic activity was obtained by testing the sample of CSF that was taken at the time of admission from an agammaglobulinemic patient who had acute meningococcal meningitis (patient no. 5). When tested at a protein concentration of 296 $\mathrm{mg} / 100 \mathrm{ml}$, this sample of CSF promoted $65 \%$ bacterial killing.

The relationship between CMOA, expressed as the percentage of bacteria that were killed, and protein concentration in CSF was further studied in the group of 15 samples of normal concentrated CSF referred to above. A sigmoidal relationship was observed when the 16-fold concentrated sam-

Table 2. Opsonization of Staphylococcus aureus variant strain Wood 46 by human cerebrospinal fluid (CSF) and serum in a phagocytic bactericidal assay.

\begin{tabular}{lcc}
\hline $\begin{array}{l}\text { Source of opsonic } \\
\text { activity, treatment }\end{array}$ & $\begin{array}{c}\text { Percentage } \\
\text { of bacterial } \\
\text { killing* }\end{array}$ & $\begin{array}{c}\text { No. of } \\
\text { experiments }\end{array}$ \\
\hline CSF & 0 & 10 \\
$\quad$ Normal, 10\% dilution & 0 & 25 \\
$\quad$ Normal, 50\% dilution & 0 & 15 \\
$\quad \begin{array}{l}\text { Normal, untreated } \\
\text { Normal, 10-fold concentration }\end{array}$ & $66-97$ & 15 \\
$\quad \begin{array}{l}\text { Normal, 10-fold concentration, } \\
\quad \text { heated } \dagger\end{array}$ & $0-2$ & 3 \\
$\quad \begin{array}{l}\text { Agammaglobulinemic, 50\% } \\
\quad \text { dilution } \ddagger\end{array}$ & 65 & 1 \\
$\begin{array}{l}\text { Serum } \\
\quad \text { Normal, 10\% dilution } \\
\text { Normal, 10\% dilution, } \\
\quad \text { heated }\end{array}$ & $90-99$ & 10 \\
$\quad \begin{array}{l}\text { Agammaglobulinemic, 10\% } \\
\text { dilution }\end{array}$ & $0-5$ & 10 \\
\hline
\end{tabular}

* Percentage of initial inoculum killed after $30 \mathrm{~min}$ of incubation. Data are ranges when more than one experiment were performed.

$\dagger$ Heated at $56 \mathrm{C}$ for $30 \mathrm{~min}$.

$¥$ This sample of CSF was obtained from a patient with acute meningitis and was tested at a protein concentration similar to that of normal CSF at a 10-fold dilution.

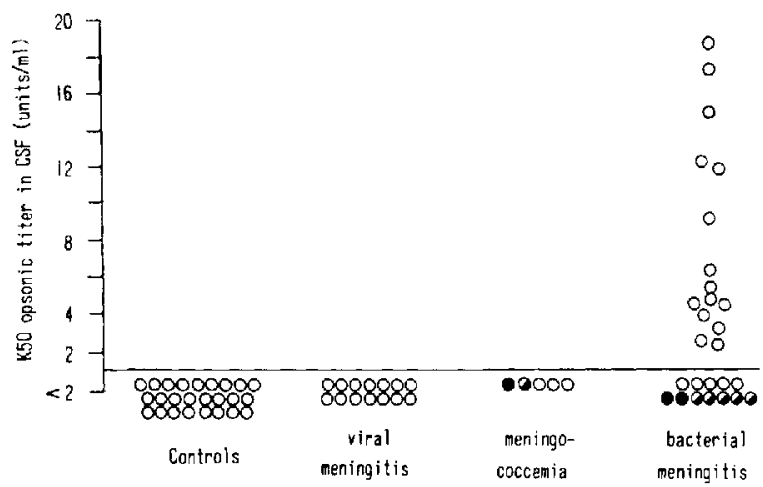

Figure 2. Complement-mediated opsonic activity measured in the cerebrospinal fluid (CSF) of 25 control patients and patients with viral meningitis (14 patients), meningococcemia (five), or bacterial meningitis (27). Clinical outcome was reported as (O) complete recovery, $(\boldsymbol{O})$ recovery with neurologic sequelae, or $(\bullet)$ death. The horizontal line represents the detection level of opsonic activity with the assay used; the first CSF dilution tested was $1: 2 . K_{s 0}$ opsonic titers were defined as the inverse of the dilution of serum or CSF that promoted $50 \%$ killing of Staphylococcus aureus variant strain Wood 46 (see Materials and Methods).

ples of CSF were serially diluted to the normal range of protein concentration in the CSF (figure 1, top). A similar sigmoidal curve was also observed when sera from the same patients were serially diluted, but the levels of bacterial killing increased at lower protein concentrations when compared with the samples of $\operatorname{CSF}(P<0.001)$. Normal CSF had to be concentrated an average of 4.2 times to kill $50 \%$ of the test bacteria. Thus, the mean $( \pm \mathrm{SD}) \mathrm{K}_{50}$ opsonic titer of the 15 samples of CSF was estimated at $0.242 \pm 0.122$ units $/ \mathrm{ml}$ of untreated CSF. By comparison, the mean $\mathrm{K}_{50} \mathrm{op}$ sonic titer in the paired sera was $151 \pm 38$ units $/ \mathrm{ml}$. When adjusted for protein concentration, $1 \mathrm{mg}$ of CSF protein corresponded to $0.82 \pm$ $0.33 \mathrm{~K}_{\text {so }}$ opsonic units as compared with $2.12 \pm$ 0.64 units in $1 \mathrm{mg}$ of serum protein $(P<0.001)$. When CMOA was expressed in $\mathrm{K}_{50}$ units, we found a linear correlation of this parameter with the CSF protein concentration $(r=0.68 ; P$ $<0.001) . \mathrm{CH}_{50}$ was also assayed in 10 of the 15 samples of concentrated CSF and was found to be positively correlated with the $\mathrm{K}_{50}$ opsonic titers ( $r$ $=0.70 ; P<0.02$ ).

$C M O A$ in inflammatory CSF. The most striking variations in the CMOA of CSF were observed in group 4 (bacterial meningitis) patients (figure 2). Because of the small volumes of the samples from patients with meningitis, CMOA could only 
be estimated at an initial CSF dilution of 1:2. At this dilution, group 1 (control patients), group 2 (patients with viral meningitis), and group 3 (patients with meningococcemia) showed complete absence of CMOA. In contrast to these results, 15 of 27 patients in group 4 had evidence of CMOA in their CSF. When further tested at serial dilutions, the CMOA-positive samples of CSF had $\mathrm{K}_{50}$ opsonic titers ranging from 2.4 to 18.5 units (mean $\pm \mathrm{SD}, 8.13 \pm 5.45$ ). These $\mathrm{K}_{s 0}$ titers of CSF were not significantly correlated with $\mathrm{K}_{50}$ titers in the corresponding sera but were correlated with the protein concentrations in inflammatory CSF $(r=$ $0.56 ; P<0.01$ ) (figure 3). Several samples of CSF, however, had undetectable levels of CMOA in spite of a marked increase in their protein concentration. The relationship between protein concentration and CMOA was further tested in the 15 CMOA-positive samples of CSF from patients with bacterial meningitis and exhibited a sigmoidal dose-response curve (figure 1, bottom) as noted above for normal CSF (figure 1, top). In contrast to the normal curve, there was no shift of the inflammatory CSF curve. Because $1 \mathrm{mg}$ of CSF protein contained $1.81 \pm 0.84$ (mean \pm SD) $\mathrm{K}_{50}$ opsonic units vs. $2.0 \pm 0.94$ units $/ \mathrm{mg}$ of serum protein (difference not significant), we concluded that the inflammatory process observed in 15 of 27 patients with bacterial meningitis restored

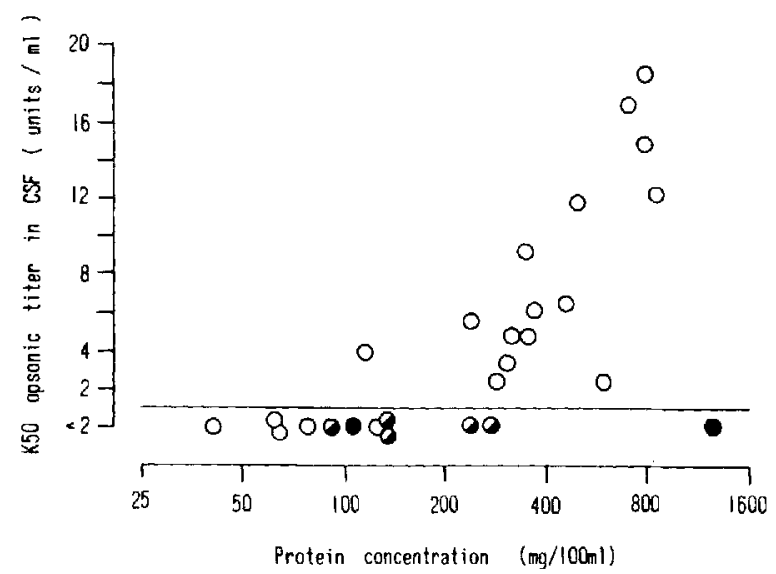

Figure 3. Opsonic activity measured in the cerebrospinal fluid (CSF) of 27 patients who had bacterial meningitis; results are expressed as a function of the protein concentration in CSF. Clinical outcome is reported as (O) complete recovery, (O) recovery with neurologic sequelae, or (O) death. The horizontal line represents the detection level of opsonic activity with the assay used; the first CSF dilution tested was 1:2.

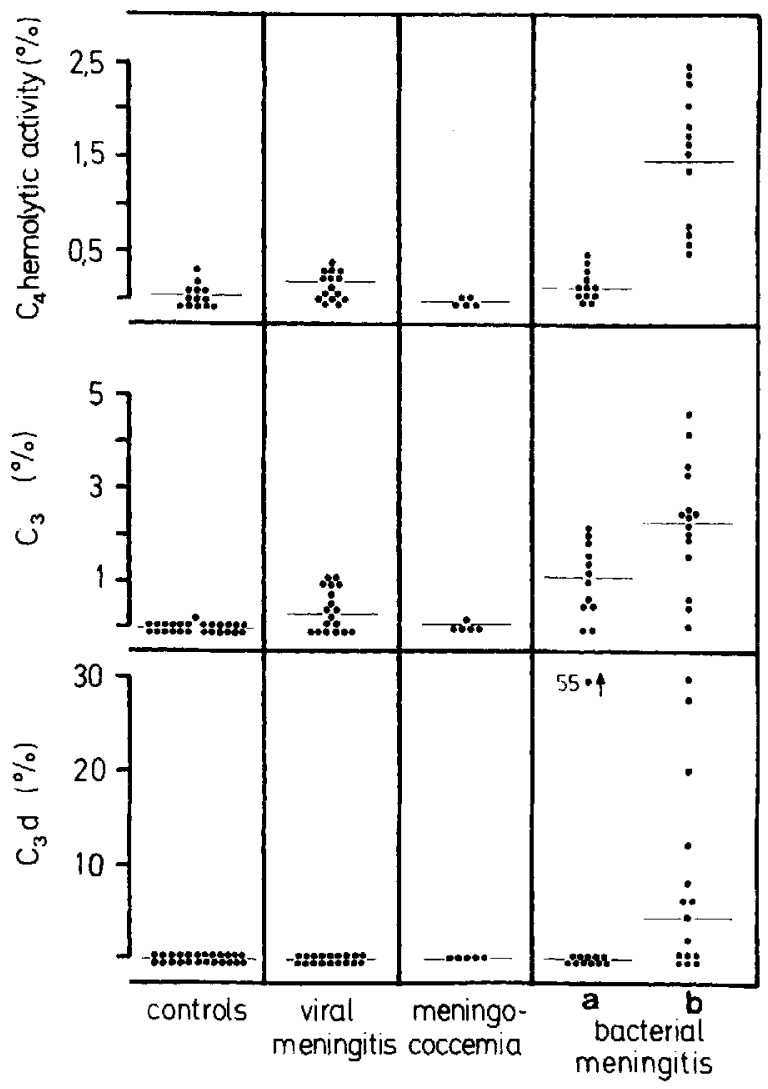

Figure 4. Levels of complement components in the cerebrospinal fluid (CSF) of control patients and patients who had viral meningitis, meningococcemia, or bacterial meningitis. The percentages of activity or concentration of complement in pooled normal plasma are shown for (top) C4 hemolytic activity, (middle) C3 concentrations, and (bottom) C3d concentrations. Patients with bacterial meningitis were divided into (a) those who had detectable and (b) those who had undetectable levels of opsonic activity in the CSF. Detectable levels of opsonic activity were defined as $\mathrm{K}_{50}$ opsonic titers (the inverse of the dilution of CSF that promoted 50\% killing of Staphylococcus aureus variant strain Wood 46) of $\geqslant 2$ units $/ \mathrm{ml}$. Horizontal lines show averages of complement levels for each group of patients.

the levels of CMOA observed in samples of uninfected CSF to those observed in serum.

CSF complement factors were assayed in the four groups of patients (figure 4); patients from group 4 were divided into two subgroups according to whether their CSF was CMOA-positive or -negative. A striking increase of $\mathrm{C} 4$ hemolytic activity was observed in the CMOA-positive samples of CSF from patients with bacterial meningitis as compared either with CMOA-negative CSF or with CSF obtained in the other three groups ( $P$ $<0.001)$. C4 activities in the CSF of patients in 
Table 3. Heat-labile opsonic activity $\left(\mathrm{K}_{50}\right)$, hemolytic activity of complement, and concentrations of complement components in sera and plasma from normal control patients and patients with acute meningitis.

\begin{tabular}{|c|c|c|c|c|}
\hline Complement factors & $\begin{array}{l}\text { Control patients } \\
\quad(n=20)\end{array}$ & $\begin{array}{c}\text { Viral } \\
\text { meningitis }(n=18)\end{array}$ & $\begin{array}{l}\text { Meningocoscemia } \\
\quad(n=5)\end{array}$ & $\begin{array}{c}\text { Bacterial } \\
\text { meningitis }(n=26)\end{array}$ \\
\hline \multicolumn{5}{|l|}{$\mathbf{K}_{50}$ opsonic titers* } \\
\hline Experimental values $\dagger$ & $151 \pm 38$ & $156 \pm 92$ & $52 \pm 34 \ddagger$ & $104 \pm 46 \ddagger$ \\
\hline Values adjusted for & & & & \\
\hline protein concentration§ & $2.12 \pm 0.64$ & $2.63 \pm 1.7$ & $0.96 \pm 0.88 \ddagger$ & $2.00 \pm 0.96$ \\
\hline \multicolumn{5}{|l|}{ Hemolytic activity of } \\
\hline $\mathrm{CH}_{50} \| \mathrm{H}$ & $96 \pm 20$ & $124 \pm 27 \ddagger$ & $52 \pm 20 \ddagger$ & $110 \pm 24$ \\
\hline $\mathrm{C} 4 \#$ & $99 \pm 27$ & $85 \pm 22$ & $77 \pm 39$ & $91 \pm 46$ \\
\hline Factor $\mathrm{B}^{\dagger}$ & $58 \pm 18$ & $54 \pm 18$ & $39 \pm 19$ & $59 \pm 21$ \\
\hline \multicolumn{5}{|l|}{ Concentration of } \\
\hline $\mathrm{C} 3^{* *}$ & $96 \pm 17$ & $100 \pm 13$ & $54 \pm 34 \sharp$ & $121 \pm 22 \ddagger$ \\
\hline $\mathrm{C} 3 \mathrm{~d}^{* *}$ & $5 \pm 8$ & $13 \pm 7$ & $33 \pm 22 \ddagger$ & $31 \pm 25 \ddagger$ \\
\hline Total protein $\dagger \dagger$ & $73 \pm 9$ & $65 \pm 7 \ddagger$ & $54 \pm 9 \ddagger$ & $56 \pm 9 \ddagger$ \\
\hline
\end{tabular}

NOTE. Data are means $\pm \mathrm{SD} ; n=$ no. of patients tested.

* The inverse of the dilution that promoted 50\% killing of Staphylococcus aureus variant strain Wood 46.

$\dagger$ Expressed as units $/ \mathrm{ml}$.

$\ddagger$ Differs significantly from control values $(P<0.01)$.

$\S$ Expressed as units $/ \mathrm{mg}$.

\| Total hemolytic activity of complement.

\# Expressed as the percentage of activity in pooled normal serum.

** Expressed as the percentage of concentration in pooled normal serum.

†† Expressed as $\mathrm{g} / \mathrm{liter}$.

group 4 showed a close correlation with $\mathrm{CSF} \mathrm{K}_{50}$ opsonic titers $(r=0.79 ; P<0.001)$ and with CSF protein concentrations $(r=0.59 ; P<0.005)$. CMOA-positive samples of CSF also showed an increase in their immunochemically measured levels of $\mathrm{C} 3$ as compared with CMOA-negative samples of CSF $(P<0.02)$. C3d, the breakdown product of $\mathrm{C3}$, was demonstrated in eight CMOApositive samples and in one CMOA-negative sample of CSF but was never detected in the CSF from patients in groups 1, 2, or 3. Levels of C3d in CSF, when expressed per milligram of protein, were three to $\mathbf{4 8}$ times higher than the protein-adjusted levels of C3d in plasma obtained from the same patients. Thus, the presence of measurable levels of CMOA in CSF of patients with bacterial meningitis is associated with an increase of $\mathrm{C} 4$ activity and $\mathrm{C} 3$ level and with evidence of local activation of $\mathrm{C} 3$.

Serum CMOA and plasma complement levels were measured in the four groups of patients to learn whether the local changes in the CSF during bacterial infection resulted from simultaneous modifications in the plasma (table 3). Definite changes were observed in the plasma of patients who had fulminant meningococcemia: lower levels of $\mathrm{K}_{50}$ opsonic titers $(P<0.01), \mathrm{CH}_{50}(P<0.001)$, and factor $\mathrm{B}$ activities $(P<0.05)$ and higher levels of C3d $(P<0.01)$ when compared with control patients (group 1). Levels of C3d also increased in the plasma of patients with bacterial meningitis when compared with group 1 subjects $(P<0.01)$. No correlation was found between the levels of either component in paired samples of CSF and plasma.

Correlation between opsonic activity of CSF and clinical course of bacterial meningitis. Among the 27 patients with bacterial meningitis, 20 recovered completely, two died from the disease, and five developed permanent neurologic sequelae. All of the 15 patients who had measurable levels of CMOA in their CSF recovered completely from the disease, whereas all seven patients who had neurologic sequelae or a lethal outcome were among the 12 patients who had undetectable levels of opsonic activity in their CSF (table 4). Therefore, the presence of CMOA in the CSF from patients with bacterial meningitis was correlated with a favorable clinical outcome $(P<0.005$; Fisher's exact test). Complete recovery was also associated with a higher mean $\mathrm{C} 4$ hemolytic activity in $\mathrm{CSF}$ $(P<0.001)$, with higher $\mathrm{C} 3$ levels $(P<0.05)$, and with a lower mean bacterial count in the sample of CSF taken at the time of admission $(P<0.001)$ (table 5). No significant differences could be observed in the mean protein concentration or in the 
Table 4. Clinical outcome in patients with bacterial meningitis and the presence of measurable opsonic activity in cerebrospinal fluid (CSF).

\begin{tabular}{lccc} 
& \multicolumn{2}{c}{$\begin{array}{c}\text { Clinical outcome } \\
\text { (no. of patients) }\end{array}$} & \\
\cline { 2 - 3 } Opsonic activity & $\begin{array}{c}\text { Complete } \\
\text { recovery }\end{array}$ & $\begin{array}{c}\text { Sequelae } \\
\text { or death }\end{array}$ & $\begin{array}{c}\text { Total no. } \\
\text { of patients }\end{array}$ \\
\hline Present & 15 & 0 & 15 \\
Absent & 5 & 7 & 12 \\
Total & 20 & 7 & 27 \\
\hline
\end{tabular}

NOTE. Samples of CSF were tested first at a dilution of $1: 2$, which corresponded to an opsonic activity of $\geqslant 2 \mathrm{~K}_{50}(50 \%$ killing) units $/ \mathrm{ml}$. The association between complete recovery and the presence of opsonic activity in CSF is statistically significant $(P<0.005$ by Fisher's exact test).

mean PMNL counts in CSF between the two groups of patients. Patient groups with a favorable or unfavorable clinical course had similar plasma $\mathrm{K}_{s_{0}}$ opsonic titers and complement levels; further analysis of the various clinical data failed to reveal a significant association of neurologic complications or death with age, sex, duration of symptoms prior to the start of antibiotic therapy, bacteremia on admission, or presence of a particular etiologic agent.

\section{Discussion}

The rationale for studying CMOA in normal and infected CSF resides in the fact that in nonimmune patients, opsonically active complement is one of the first defense mechanisms against pathogenic organisms [37, 38] and might contribute to host defense at an early phase of bacterial meningitis when specific antibodies are still lacking. The data presented above demonstrate that CMOA was undetectable in normal untreated CSF but was measurable after concentration; levels of CMOA also remained undetectable in the unconcentrated CSF of patients who had viral meningitis or fulminant meningococcemia at an early stage of the disease when noninflammatory CSF was already culturepositive. In contrast, CMOA appeared in 15 of 27 samples of CSF obtained during the early phase of bacterial meningitis, and its presence was correlated with a favorable clinical outcome. Such a favorable clinical evolution was also associated with an increase in complement levels and with lower concentrations of infecting microorganisms in CSF.

Several methodologic aspects of the technique used in this study should be discussed. In our phagocytic assay we did not use encapsulated bacteria causing meningitis as biological effectors; we used S. aureus strain Wood 46 because we wanted to measure early, nonspecific, functional CMOA in $\mathrm{CSF}$, rather than individual immune response to specific microorganisms in nonimmune patients. Furthermore, it is generally accepted that bacterial meningitis develops only in patients who lack type-specific, functional serum antibodies [39]. It is therefore likely that the study of early, specific immune response in CSF to the offending organisms would have given negative results. For ethical reasons, the phenomenon of the time-dependent appearance of specific antibodies can only be examined in an animal model. Previous studies in our laboratory have shown that the opsonization

Table 5. Correlation of clinical outcome in patients with bacterial meningitis and $\mathrm{K}_{50}(50 \% \mathrm{killing})$ opsonic titers, complement levels, and bacterial counts in cerebrospinal fluid (CSF).

\begin{tabular}{lccc} 
CSF factors & $\begin{array}{c}\text { Complete recovery } \\
(n=20)\end{array}$ & $\begin{array}{c}\text { Sequelae or death } \\
(n=7)\end{array}$ & $\begin{array}{c}\text { Association with } \\
\text { recovery }\end{array}$ \\
\hline Kso opsonic titers (units/ml)* & $6.1 \pm 5.91$ & $<2$ & $P<0.005$ \\
C4 hemolytic activity $\dagger$ & $1.12 \pm 0.90$ & $0.15 \pm 0.13$ & $P<0.01$ \\
Concentration of $\mathrm{C}{ }^{\dagger}$ & $0.50 \pm 0.34$ & $0.32 \pm 0.19$ & $P<0.05$ \\
Bacterial counts $(\log \mathrm{cfu} / \mathrm{ml}) \ddagger$ & $5.11 \pm 1.16$ & $7.22 \pm 0.75$ & $P<0.001$ \\
Protein concentration $(\mathrm{mg} / 100 \mathrm{ml})$ & $372 \pm 268$ & $160 \pm 74 \$$ & NS \\
\hline
\end{tabular}

NOTE. Data are means \pm SD and probabilities of association with recovery calculated by Fisher's exact test. NS $=$ not significant.

${ }^{*} \mathrm{~K}_{\mathrm{s} \theta}=$ the inverse of the dilution of CSF that promoted $50 \%$ killing of Staphylococcus aureus variant strain Wood 46.

$\dagger$ Expressed as the percentage of activity or concentration in pooled normal serum.

$\ddagger$ Performed in samples from 10 patients who recovered and from five patients who either died or had sequelae.

$\S$ Mean calculated for six of the seven patients who either died or had sequelae; patient no. 23 was excluded because of an unusually high concentration of protein in the CSF $(1,230 \mathrm{mg} / 100 \mathrm{ml})$. 
of $S$. aureus strain Wood 46 by human serum depends mainly on the complement system, and the role played by antibody is minimal [29]. The results of the present studies, which use CSF as the source of opsonic activity, confirm the earlier data (table 2). The correlation found between CMOA and $\mathrm{CH}_{50}$ in 10 samples of normal concentrated CSF $(P<0.02)$ and between CMOA and $\mathrm{C} 4$ activities in samples of CSF from patients with meningitis $(P<0.001)$ provides further evidence that the heat-labile opsonic activity in CSF that was measured by our phagocytic assay was indeed complement-mediated.

The method used to obtain and store CSF samples for measurement of complement levels or opsonic activity turned out to be a crucial methodologic point; spontaneous decay of complement occurs in untreated frozen CSF [15] and may even be accelerated when CSF that is taken from patients with systemic lupus erythematosus and central nervous system involvement is stored at -45 $C$ [40]. To minimize this problem, all samples of CSF were drawn into vials containing EDTA and were immediately frozen at $-70 \mathrm{C}$. Blood contamination of the CSF, which would have resulted in falsely high levels of complement activities, was eliminated by excluding all CSF samples with an admixture of blood of $\geqslant 1: 25,000$.

We started our study with the hypothesis that the phagocytic test developed by Lew et al. [29] could be adapted to untreated CSF because the mean $\mathrm{K}_{50}$ opsonic titers measured in pooled serum (236 units $/ \mathrm{ml}$ ) approximated the protein ratio found between normal untreated CSF and serum (1:250). However, CMOA was not detected in fresh undiluted CSF with this assay. By concentrating large volumes of normal CSF obtained during gas myelography, we were able to show that normal untreated CSF was devoid of CMOA. The absence of CMOA in CSF was evidenced by the low protein concentration in CSF; moreover, CMOA, expressed per milligram of protein, could be demonstrated to be lower in the CSF than in the serum from the same patient (figure 1, top). These findings are consistent with the data of Tofte et al. [17], who described an absence of opsonization of various encapsulated bacteria by normal CSF, whereas one sensitive strain of $S$. aureus (strain 502A) was opsonized by CSF. Our results are also in agreement with those published by Simberkoff et al. [18], who used various pathogenic and non- pathogenic test bacteria and showed no bactericidal and no opsonic activity in normal CSF.

Our experiments with concentrated CSF suggest that the opsonic defect is not qualitative but merely quantitative. Sensitization of the phagocytic test by ultrafiltration had the additional advantages of eliminating all potential traces of antibiotics and EDTA from the samples and allowing us to test CSF under native conditions but in a well-buffered system. To minimize any error introduced by manipulating the CSF, we systematically prepared each sample of CSF and serum by ultrafiltration shortly before use. Control experiments showed that the ultrafiltration-concentration procedure resulted in a minimal, reproducible loss of CMOA and was not accompanied by any evidence of complement activation.

Early appearance of CMOA in CSF during bacterial meningitis-as opposed to viral meningitis - was paralleled by increases in C3 activity and $\mathrm{C} 3$ levels, which confirmed the presence of $\mathrm{CH}_{50}$ [18] and various other complement components $[24,41,42]$ in the CSF of patients with meningitis. The early appearance of CMOA in $\mathrm{CSF}$ was further correlated with changes in the protein concentrations in CSF early in the course of the disease. $\mathrm{K}_{50}$ opsonic titers in the CSF, however, when adjusted for protein concentration, never exceeded $\mathbf{K}_{50}$ values in serum, which were also adjusted for protein concentration. It is therefore probable that the appearance of CMOA in CSF is one of the numerous changes induced by local inflammation of the subarachnoid space. The appearance of CMOA may be the result of an increase in the permeability of the blood-brain barrier for large molecules, as suggested by the appearance of IgM in infected CSF [23]. A part of complement is probably activated in the CSF during meningitis, as evidenced by the presence of $\mathrm{C} 3 \mathrm{~d}$, the breakdown product of $\mathrm{C} 3$, in the CSF of nine patients.

The clinical relevance of the correlation found between the presence of CMOA in the CSF and a favorable clinical outcome for patients with bacterial meningitis needs to be put in proper perspective. First, $\mathrm{CMOA}$ - as assessed by the phagocytic assay with $S$. aureus strain Wood 46-does not measure possible specific opsonins in CSF and serum or the bactericidal defense mechanisms that each patient produces in response to the particular microorganism that causes the infection. How- 
ever, these factors are unlikely to be present initially and were undetectable in the CSF of patients with acute bacterial meningitis [18]. In contrast, complement activity - as measured in our assay is a nonspecific but immediately available host defense factor [38], and its level in the CSF may be important in limiting the rate of bacterial growth, as shown under other conditions [25, 37, 43]. Also, it should be stressed that the association between the presence of CMOA in the CSF and a favorable outcome for patients with meningitis is purely descriptive and that the present data do not prove a causal relationship. In fact, we cannot exclude the possibility that a common mechanism (for example, greater permeability of the bloodCSF barrier for both complement components and antibiotics) simultaneously influences several factors. However, patients who recovered completely from meningitis not only had higher $\mathrm{K}_{50}$ opsonic titers but also had lower mean initial bacterial counts in their CSF than did patients with complications, as previously observed by Feldman [20]. Thus, any mechanism that is able to moderate bacterial growth in the CSF may be an important determinant of the course of the disease and may allow the patient to receive medical therapy before complications arise. The possibility that CMOA in CSF might not merely reflect the permeability of the blood-meningeal barrier but may express an important biologic role of complement that is independent of the inflammatory process is illustrated by one subject in our study. Patient no. 23 had fatal post-traumatic meningitis due to E. coli; his initial sample of CSF contained over $10^{8} \mathrm{cfu}$ of bacteria $/ \mathrm{ml}$ and had undetectable levels of $\mathrm{C} 4, \mathrm{C} 3$, and opsonic activity, in spite of a massive increase in protein concentration in the CSF. This situation was associated with very high levels of C3d, the breakdown product of C3, in the CSF. Thus, bacterial infection of the subarachnoid space may occasionally lead to a state of local consumption of opsonins and complement as previously demonstrated for pleural empyema [29, $44,45]$.

Our results show that despite its barely detectable concentration in normal CSF, CMOA rapidly appears during the course of bacterial meningitis. The current results suggest that CMOA in CSF might be one of the numerous factors that influence the outcome of the disease. Increasing the level of opsonic activity in the CSF had already been suggested in the preantibiotic era [46] as a means of influencing the outcome of bacterial meningitis, and this therapeutic strategy can now be evaluated in animal models.

\section{References}

1. Dodge, P. R., Swartz, M. N. Bacterial meningitis-a review of selected aspects. II. Special neurologic problems, postmenigitic complications and clinicopathological correlations. N. Engl. J. Med. 272:954-960, 1965.

2. Hodges, G. R., Perkins, R. L. Acute bacterial meningitis: an analysis of factors influencing prognosis. Am. J. Med. Sci. 270:427-440, 1975.

3. Feigin, R. D., Dodge, P. R. Bacterial meningitis: newer concepts of pathophysiology and neurologic sequelae. Pediatr. Clin. North Am. 23:541-556, 1976.

4. Scheld, W. M. Pathophysiologic correlates in bacterial meningitis. Journal of Infection 3(Suppl. 1):5-20, 1981.

5. Robbins, J. B., McCracken, G. H., Jr., Gotschlich, E. C., Ørskov, F., Ørskov, I., Hanson, L. A. Escherichia coli K1 capsular polysaccharide associated with neonatal meningitis. N. Engl. J. Med. 290:1216-1220, 1974.

6. Moxon, E. R., Murphy, P. A. Haemophilus influenzae bacteremia and meningitis resulting from survival of a single organism. Proc. Natl. Acad. Sci. U.S.A. 75:15341536, 1978.

7. Petersdorf, R. G., Swarner, D. R., Garcia, M. Studies on the pathogenesis of meningitis. II. Development of meningitis during pneumococcal bacteremia. J. Clin. Invest. 41:320-327, 1962.

8. Moxon, E. R., Ostrow, P. T. Haemophilus influenzae meningitis in infant rats: role of bacteremia in pathogenesis of age-dependent inflammatory responses in cerebrospinal fluid. J. Infect. Dis. 135:303-307, 1977.

9. Scheifele, D. W., Daum, R. S., Syriopoulou, V. P., Averill, D. R., Smith, A. L. Haemophilus influenzae bacteremia and meningitis in infant primates. J. Lab. Clin. Med. 95:450-462, 1980.

10. Scheld, W. M., Park, T.-S., Dacey, R. G., Winn, H. R., Jane, J. A., Sande, M. A. Clearance of bacteria from cerebrospinal fluid to blood in experimental meningitis. Infec. Immun. 24:102-105, 1979.

11. McAllister, C. K., O'Donoghue, J. M., Beaty, H. N. Experimental pneumococcal meningitis. II. Characterization and quantitation of the inflammatory process. J. Infect. Dis. 132:355-360, 1975.

12. Scheld, W. M., Dacey, R. G., Winn, H. R., Welsh, J. E., Janc, J. A., Sande, M. A. Cerebrospinal fluid outflow resistance in rabbits with experimental meningitis: alterations with penicillin and methylprednisolone. J. Clin. Invest. 66:243-253, 1980.

13. Tibbling, G., Link, H., Öhman, S. Principles of albumin and $\mathrm{IgG}$ analyses in neurological disorders. I. Establishment of reference values. Scand. J. Clin. Lab. Invest. 37:385-390, 1977.

14. Propp, R. P., Jabbari, B., Barron, K. Measurement of the third component of complement in cerebrospinal fluid by modified electroimmunodiffusion. J. Lab. Clin. Med. 82:154-157, 1973. 
15. Petz, L. D. Measurement of spinal fluid complement in immunologically mediated neurologic disorders. In $\mathrm{W}$. Opferkuch, K. Rother, and D. R. Schultz [ed.]. Clinical aspects of the complement system. Georg Thieme, Stuttgart, Federal Republic of Germany, 1978, p. 125-128.

16. Cova, J. L., Propp, R. P., Barron, K. D. Quantitative relationships of the fourth complement component in human cerebrospinal fluid. J. Lab. Clin. Med. 89:615$621,1977$.

17. Tofte, R. W., Peterson, P. K., Kim, Y., Quie, P. G. Opsonic activity of normal human cerebrospinal fluid for selected bacterial species. Infec. Immun. 26:1093-1098, 1979.

18. Simberkoff, M. S., Moldover, N. H., Rahal, J. J., Jr. Absence of detectable bactericidal and opsonic activities in normal and infected human cerebrospinal fluids: a regional host defense deficiency. J. Lab. Clin. Med. 95: 362-372, 1980.

19. Petersdorf, R. G., Luttrell, C. N. Studies on the pathogenesis of meningitis. I. Intrathecal infection. J. Clin. Invest. 41:311-319, 1962.

20. Feldman, W. E. Relation of concentrations of bacteria and bacterial antigen in cerebrospinal fluid to prognosis in patients with bacterial meningitis. N. Engl. J. Med. 296: 433-435, 1977.

21. Nolan, C. M., Clark, R. A., Beaty, H. N. Experimental pneumococcal meningitis. 1II. Chemotactic activity in cerebrospinal fluid. Proc. Soc. Exp. Biol. Med. 150: 134-136, 1975.

22. Greenwood, B. M. Chemotactic activity of cerebrospinal fluid in pyogenic meningitis. J. Clin. Pathol. 31:213$216,1978$.

23. Ganrot-Norlin, K. Relative concentrations of albumin and IgG in cerebrospinal fluid in health and in acute meningitis. Scand. J. Infect. Dis. 10:57-60, 1978.

24. Whittle, H. C., Greenwood, B. M. Cerebrospinal fluid immunoglobulins and complement in meningococcal meningitis. J. Clin. Pathol. 30:720-722, 1977.

25. Stossel, T. P. Phagocytosis [part 1]. N. Engl. J. Med. 290: 717-723, 1974.

26. Lennette, E. H., Balows, A., Hausler, W. J., Jr., Truant, J. P. [ed.]. Manual of clinical microbiology. 3rd ed. American Society for Microbiology, Washington, D.C., 1980, p. 1-440.

27. Feldman, W. E. Concentrations of bacteria in cerebrospinal fluid of patients with bacterial meningitis. J. Pediatr. $88: 549-552,1976$.

28. Hirsch, J. G., Strauss, B. Studies on heat-labile opsonin in rabbit serum. J. Immunol. 92:145-154, 1964.

29. Lew, P. D., Zubler, R., Vaudaux, P., Farquet, J. J., Waldvogel, F. A., Lambert, P.-H. Decreased heat-labile opsonic activity and complement levels associated with evidence of $\mathrm{C} 3$ breakdown products in infected pleural effusions. J. Clin. Invest. 63:326-334, 1979.

30. Nydegger, U. E., Achermann, L. M., Lambert, P.-H., Miescher, P. A. A simple automated method for complement estimation in a continuous flow system. J. Immunol. 109:910-913, 1972.

31. Frank, M. M., May, J., Gaither, T., Ellman, L. In vitro studies of complement function in sera of C4-deficient guinea pigs. J. Exp. Med. 134:176-187, 1971.

32. Aguado, M. T., Perrin, L. H., Ramirez, R., Miescher,
P. A., Lambert, P.-H. Evaluation of alternative pathway and factor $B$ haemolytic activities in patients with systemic lupus erythematosus: correlations with the alternative pathway regulatory proteins. Clin. Exp. Immunol. 42:495-505, 1980.

33. Perrin, L. H., Lambert, P.-H., Nydegger, U. E., Miescher, P. A. Quantitation of C3PA (properdin factor B) and other complement components in diseases associated with a low $\mathrm{C} 3$ level. Clin. Immunol. Immunopathol. 2:16-27, 1973.

34. Perrin, L. H., Lambert, P.-H., Miescher, P. A. Complement breakdown products in plasma from patients with systemic lupus erythematosus and patients with membranoproliferative or other glomerulonephritis. J. Clin. Invest. 56:165-176, 1975.

35. Meddis, R. Statistical handbook for non-statisticians. McGraw-Hill, Maidenhead, Berkshire, England, 1975, p. 48-56.

36. Wagner, J. G. Fundamentals of clinical pharmacokinetics. Drug Intelligence Publications, Hamilton, Ill., 1975, p. 316-317.

37. Winkelstein, J. A., Smith, M. R., Shin, H. S. The role of $\mathrm{C} 3$ as an opsonin in the early stages of infection. Proc. Soc. Exp. Biol. Med. 149:397-401, 1975.

38. Fearon, D. T., Austen, K. F. The alternative pathway of complement - a system for host resistance to microbial infection. N. Engl. J, Med. 303:259-263, 1980.

39. McGee, Z. A., Kaiser, A. B. Acute meningitis. In G. L. Mandell, R. G. Douglas, Jr., and J. E. Bennett [ed.]. Principles and practice of infectious diseases. Vol. 1. Wiley, New York, 1979, p. 738-760.

40. Hadler, N. M., Gerwin, R. D., Frank, M. M., Whitaker, J. N., Baker, M., Decker, J. L. The fourth component of complement in the cerebrospinal fluid in systemic lupus erythematosus. Arthritis Rheum. 16:507-521, 1973.

41. Fothergill, L. D. Observations on the presence of complement in the cerebrospinal fluid in various pathologic conditions of the central nervous system. J. Pediatr. 6:374-381, 1935.

42. Spicer, S., Appelbaum, E., Rutstein, D. D. Complement and its component fractions in cerebrospinal fluid in inflammatory cerebrospinal diseases. J. Clin. Invest. 28: 389-393, 1949.

43. Forsgren, A., Quie, P. G. Influence of the alternate complement pathway on opsonization of several bacterial species. Infec. Immun. 10:402-404, 1974.

44. Suter, S., Nydegger, U. E., Roux, L., Waldvogel, F. A. Cleavage of $\mathrm{C} 3$ by neutral proteases from granulocytes in pleural empyema. J. Infect. Dis. 144:499-508, 1981.

45. Lew, D. P., Despont, J.-P., Perrin, L. H., Aguado, M.-T., Lambert, P.-H., Waldvogel, F. A. Demonstration of a local exhaustion of complement components and of an enzymatic degradation of immunoglobulins in pleural empyema: a possible factor favouring the persistence of local bacterial infections. Clin. Exp. Immunol. 42:506$514,1980$.

46. Fondé, E. C. The use of fresh human serum (complement) in combination with the antiserum in the treatment of meningococcic meningitis. J.A.M.A. 105:110-112, 1935. 